\title{
Sciendo APPLICATION OF REDUNDANCY IN SHIP POWER PLANTS OF OFFSHORE VESSELS
}

DOI 10.2478/ntpe-2018-0055

\author{
Prof. Wieslaw Tarelko \\ Gdansk University of Technology, Poland
}

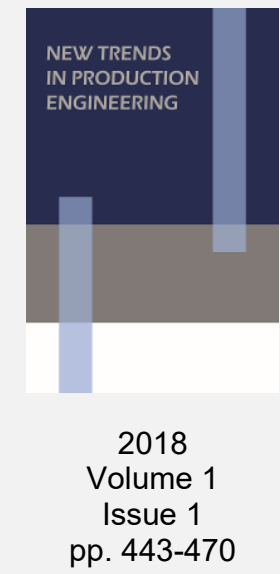

\begin{abstract}
Power and propulsion systems of offshore units must be of a very high level of reliability. The loss of ability to perform functions of their components causes generally to very high economic losses, which may be increased by unused the weather window resulting to postponing the planned offshore operations. To ensure carrying out so expensive offshore operations in the most reliable way, various types of redundancies are built-in ship power plants. This paper deals with issues related to application of redundancy in ship power plants of offshore vessels. Especially, evolution of redundancy application in ship power plants, and design solution of redundancy for offshore vessels are presented. Moreover, the specifics of these offshore operations so important from the point of view of minimizing financial losses due to any interruptions caused by failures of power and propulsion systems are discussed in detailed way.
\end{abstract}

Keywords: redundancy, reliability, ship power plant, offshore vessel

\section{INTRODUCTION}

In principle, a high level of technical systems' availability, including ship power plants of offshore vessels, can be obtained by increasing:

- the quality of the system components,

- the redundancy of system's structural components.

The first of these methods requires applying high quality technical units (parts, assemblies, systems, etc.). Their quality should be confirmed during a design process by carrying out various types of engineering analysis (e.g. fault tree analysis) and test prototypes, and then eventually proved in operational practice. This is the way, which allows us to obtain the brand products and to withdraw low quality products from marine practice. Unfortunately, it is also much more expensive way to increase the availability level of technical systems.

The second of the mentioned methods, which is reflected inter alia in the rules of classification societies (Det Norske Veritas, 2011, Polski Rejestr Statków, 2018) consists of applying the structural redundancy in technical systems. It permits redistribution of internal forces in case of failure of key elements. In principle, requirements of classification societies come down to turn ship-owners on to use of two (or more) system components of 'questionable' quality instead of one with higher quality. It is a compromise practice very well known in marine industry. It can be justified that a level of availability can be increased by carrying our preventive and corrective maintenance of system components with structural redundancy. Within the meaning of some ship operators, it is more convenient to employ well-trained marine engineers who could conduct maintenance operations during a voyage than to install expensive system components with a high level quality.

Nevertheless, there are offshore units, in which both of the mentioned ways have to be applied simultaneously. To them we can include oil exploration and drilling vessels, offshore support vessels, offshore production vessels, and construction vessels.

Two factors justified such an approach:

- a high cost of carrying out offshore operations, 
- marine environment limiting the possibility to carry out these operations in time.

On the one side, the costs of these operations are relatively expensive and can reach few hundred thousand USD. On the other side, some offshore operations can be carried out only in so called 'weather window' that is when weather forecasts indicate that a given set of offshore activities can be performed within their maximum limits for wave height, wind speeds etc.

Therefore, power and propulsion systems of offshore units must be of a very high level of reliability (more precisely - a high level of system component reliabilities). The loss of ability to perform functions of system components causes generally to very high economic losses, which may be increased by unused the earlier mentioned weather window resulting to postponing the planned offshore operations.

To ensure carrying out so expensive offshore operations in the most reliable way, various types of redundancies are built-in ship power plants. Moreover, ship-operators also consider a possibility to introduce so-called leadership redundancy (Johannessen et al., 2015). These leaders could manage these operations in case of the unavailability one of them.

This paper deals with issues related to application of redundancy in ship power plants of offshore vessels. Especially, evolution of redundancy application in ship power plants, and design solution of redundancy for offshore vessels are presented.

\section{EVOLUTION OF REDUNDANCY APPLICATION IN SHIP POWER AND PROPULSION SYSTEMS}

Historically, the power and propulsion systems were designed as a single whole setting up a ship power plant, i.e.:

- one main engine coupled with one propeller by one driveline ensured the ship motion,

- two (or more) auxiliary engines driving generators delivered electric power,

- one boiler (or more) supplied heat.

In accordance with such a concept of the ship power plant, these sources of power generation have been designed as separate systems. In recent years, the increased requirements regarding to navigation safety as well as to energy efficiency forced the necessity of design the ship power plants with high degree of integration. Accidents of crude oil tankers Amoco Cadiz and MV Braer due to the failures of their steering gear and propulsion accelerated this necessity. Amoco Cadiz was a very large crude carrier (VLCC). On 16 March 1978, she ran aground on Portsall Rocks near the coast of Brittany and ultimately split and sank, resulting in the largest oil spill. Due to a failure of steering gear the vessel loses its maneuverability (Center for Tankship Excellence, 2010). One of the consequences of this accident was the introduction to the convention SOLAS 74 requirements of the structural redundancy for steering gear of oil tankers. The MV Braer was an oil tanker which ran aground during a storm off Shetland in January 1993. Nearly a week later she broke up during the most intense extratropical cyclone on record for the northern part of the Atlantic Ocean resulting in the largest oil spill. The ship lost power due to seawater contamination of the ship's heavy fuel oil. This occurred after a pipeline on the deck broke loose, allowing seawater to enter the vessel's bunker tanks via broken air vents (Marine Accident Investigation Branch reports, 2015). The subsequent spills of large quantities of crude oil had caused considerable public attention and tremendous damage to the marine and coastal environment.

Therefore, on the forum of the International Maritime Organization (IMO) raised the votes to enter to the SOLAS Convention requirement of the structural redundancy to marine systems which are important from the navigation safety point of view.

The IMO is a specialized agency of the United Nations deals with international shipping. Its primary purpose is to develop and maintain a comprehensive regulatory framework for shipping and its remit today includes: safety, environmental concerns, legal matters, etc. In order to achieve its objectives, the IMO has promoted the adoption of some documents such as conventions, codes and recommendations concerning maritime safety, the prevention of pollution and related matters. In order to apply them to the ships, they first should be generated, prepared and recorded. Depending on the safety requirement origins, the IMO actions can get 
the reactive or proactive character. Reactive actions are used in response to a particular situation being observed, whereas proactive actions involve acting in advance of a future situation, rather than just reacting. It means taking control and making things happen rather than just adjusting to a situation or waiting for something to happen (Tarelko, 2012).

The concept of introducing redundancy to power and propulsion systems for oil tankers appeared already in the fifties of XX century in the United States (Spyrou, 2006). Corporation Bethlehem Steel Corporation has developed the project of an oil tanker ST Manhattan to carry 100000 tonnes of crude oil. In 1958 it has been performed research at the ship model basin. However, the resulting crisis in the oil market forced the company to abandon the construction of this oil tanker.

This approach was continued in the future and some shipowners have started to introduce the redundancy to power and propulsion systems of oil tankers and their types of vessels including passenger ships.

Taking into account that the power and propulsion systems are most important from the navigation safety point of view, this issue has been addressed to the relevant bodies of the IMO. In SOLAS the regulations covering the power and propulsion systems are distributed throughout the whole document and cover aspects such as having sufficient means a number of starting attempts for the main engine, ensuring availability of essential services, fire and explosion prevention and means of control. Some of the safety regulations have come about as reaction to incidents and accidents - many tragic - rather than being proactive. Examples of this are the requirement for double walled fuel lines and for some engines to be fitted with crankcase oil mist detectors or engine bearing temperature monitors (SOLAS II-2/15.2.9, International Maritime Organization, 2014).

For some ship types, redundancy of systems is a requirement, but the choice of the power and propulsion systems is not regulated meaning that ship-owners are free to choose their own combination of the increasing number on offer.

Another example is that since 2010 passenger vessels have been required to have redundant engine systems. In SOLAS convention, this aspect is reflected in rule II-2/21. It introduced new concepts of "casualty threshold", "safe area", "safe return to port". It is obvious that these socalled "safe return to port" rules have an impact on design of the ship power plants forced the structural redundancy for power and propulsion, electricity production, and steering systems.

This regulation states that in addition to the main drive system, vessels must be equipped with a second independent drive system, which in the case of failure of the main drive system shall ensure that the ship can independently lead further inland. A detailed analysis of this requirement can be found in (Vogler et al., 2009). The necessity to assess the capability of each concerned system to remain operational after a flooding or a fire casualty will require new studies at a very early stage of design.

This new approach is reflected in regulations of classification societies which have developed requirements regarding to the structural redundancy of power and propulsion systems for various types of vessels (American Bureau of Shipping, 2015, Det Norske Veritas, 2011, Polski Rejestr Statków, 2018). Some of these requirements recommend separation of these systems by means of their location in separate engine rooms to protect a loss of propulsion in case of flooding or fire in one of these compartments.

The first of the vessels that meet the requirements of the American Bureau of Shipping (ABS) were 5 crude oil tankers class Polar Endeavour. They entered into service in the years 20012005. In accordance with ABS requirements for this class of oil tankers, in addition to the double hull skin and two independent steering gears, they are equipped with two independent engine rooms (Levine et al., 2005). These compartments are separated by fire-resistance bulkheads. The first ship complying with the guidelines (Det Norske Veritas, 2011), was an oil tanker Stena Vision class V-MAX. This ship was equipped with two systems, in which two main engines drive two propellers by two independent marine shafts (Wärtsilä Encyclopedia of Marine Technology, 2015). Naturally, the engines were placed in the separate engine rooms isolated from each other by fire-resistance bulkheads. 
In recent times, ship-owners begun to use similar solutions in relation to the large containerships, for example Mærsk Mc-Kinney Møller class Triple-E. It was launched in the year 2013 as the biggest and longest containership at the time in the world (The Telegraph, 2013). As in case of the mentioned tankers, this containership has two independent power and propulsion systems, in which two main engines drive two propellers by means of two separated lines of shafts.

With regard to passenger ships, the similar solutions began to use much earlier. Despite application of a high level of redundancy of their power and propulsion systems, and separation of machine compartments, some malfunctions occurred in their ship power plants which threaten the safety of ships.

An expressive example of this is a voyage of the cruise ship Carnival Triumph (year of build: 1999). In 2013 the engine room fire stranded her at sea for several days with a loss of power that deactivated not only her propulsion, but also support systems.

The power loss was a result of the activation of the automatic fire suppression system. Other unfortunate results were inoperational air conditioning, elevators, all toilets, the kitchen equipment, the fresh-water system. After five days, the ship was towed by few tugs to the nearest harbor.
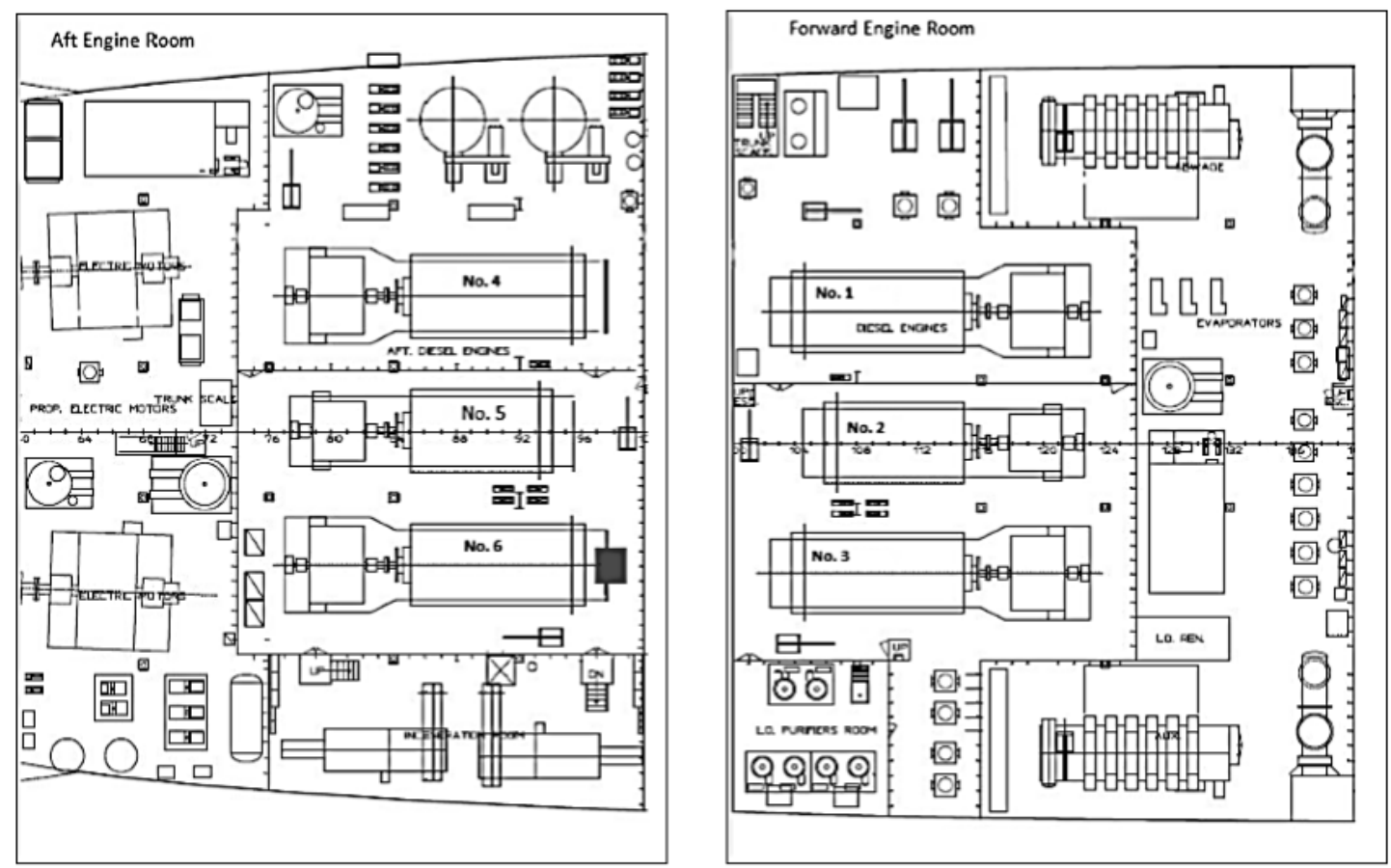

Source of Fire

Fig. 1. Arrangement of Carnival Triumph ship power plant.

Source: The Bahamas Maritime Authority, 2013

The Bahamas Maritime Authority investigated this incident at sea for discovering any lessons which may be learned and to ascertain whether any changes to the present IMO regulations are desirable with a view to preventing any repetition. According to the investigation report (The Bahamas Maritime Authority, 2013) the sequence of events was as follows:

- a flexible pipe in the fuel oil return line forward of the No. 6 engine, located in the center section of the aft engine room (Fig. 1), failed in service,

- fuel oil, mist and vapour, under pressure of 10 bar and temperature of $122^{\circ} \mathrm{C}$, sprayed upwards from below the floor plates,

- fuel oil contacted a hot spot in the vicinity of the turbocharger for the No. 6 diesel generator, resulting in a flash fire that severely damaged diesel generators Nos. 5 and 6 ,

- the main cabling overhead in the aft engine room serving the switchboard rooms was also damaged resulting in a loss of power from generators Nos.1, 2 and 3 in the forward engine room, 
- the port and starboard propulsion electrical motors (PEM) were also damaged, thereby disabling the propulsion irrespective of the generator cables,

- generator No. 4 and the switchboards did not suffer cable damage, as it is located in the port side section of the aft engine room; however, this engine was out of service for overhaul at the time of the event.

Fires of ship power plants took place in the past onboard other cruisers: Carnival Splendor (year of build: 2008) in 2010 in the Pacific Ocean, Ocean Star Pacific (year of build: 1971) in 2011 near the coast of Mexico, MSC Opera (year of build: 2004) in the 2011 on the Baltic Sea, and the Costa Allegra (year of build: 1969) in the 2011 near Seychelles Islands.

Moreover, in 2012 on board a cruise ship Azamara Quest happened the same thing as the Carnival Triumph. A fire temporarily disabled the ship, carrying 1001 passengers and crew in waters south of the Philippines. Five crew were injured in the fire and none of the passengers were injured. After drifting for 24 hours, the crew was able to restore partial power and electricity and she was able to make it to port on its own.

The design of each of these cruise ships should make the complete loss of propulsion and main generators due to a single engine fire impossible. All these ships have similar machinery arrangements. They are, as the most modern cruise ships, all diesel electric powered. Instead of having one or more large engines connected to propellers, these ships use several smaller engines connected to generators which supply electricity to the motors which turn the propellers. Typically, these ships have two independent engine rooms with three diesel engines in each. Having two separate engine rooms and six diesel engines driving generators should provide the complete redundancy. Even if one engine room is completely out of service, the diesel engines in the other engine room should be able to provide enough power to bring the ship home as well as generating enough electricity to keep the passengers comfortable.

Nevertheless, seven similar accidents within two years give arguments for finding that the design stage were committed system errors. The investigation report released after the Carnival Splendor accident has been passed to the IMO for further consideration in order to take appropriate countermeasures increasing the navigation safety of passenger ships.

\section{SHIP POWER PLANT REDUNDANCY OF OFFSHORE VESSELS Provisions of classification societies}

Despite these cruise ship events, more and more types of vessels are built based on regulations of the classification societies relating to redundancy of their power and propulsion systems. It is clear that their main objective is mainly to ensure the safety of passengers and crew. However, in some cases, application of such a redundancy is intended to minimize financial losses connected with any interruptions in carrying out the offshore operation caused by power and propulsion system failures. To these operation, we can include: oil and gas exploration, installation of the drilling and production platforms, installation of subsea equipment transporting of oil and gas etc.

Most of present offshore vessels are built to meet the rules of classification societies in the field of structural redundancy power and propulsion systems, for example the requirements of the DNV. The DNV regulations require a such design of redundancy of these systems that in cases of:

- a single failure of them ('DNV class notation RP' - Redundant Propulsion),

- a failure caused by fire or flooding ('DNV class notation RPS' - Redundant Propulsion and Separate),

at least $50 \%$ of the propulsion power can be restored before the vessel has lost the steering speed.

This means that the designed vessels must have the structural redundancies of their power and propulsion systems, and these systems have to be located in the separate machine compartments.

To illustrate how it is implemented in practice, we consider the following offshore vessels:

- a survey seismic vessel Ramform Thetys, 
- an offshore construction vessel North Sea Giant.

In particular, the specifics of these offshore operations, so important from the point of view of minimizing financial losses due to any interruptions caused by failures of power and propulsion system, are discussed in detailed way.

\section{Survey seismic vessel Ramform Thetys}

The main role in locating of offshore oil and gas reserves plays the seismic survey techniques. The recordings received from seismic surveys are transformed into visual images of the subsurface of the earth in the seismic survey area.

In such offshore operations (Fig. 2):

- the survey seismic (SSV) tows a collection of cables with seismic sources hydrophones attached,

- the seismic sources (air guns) use compressed air to produce acoustic energy,

- the receivers (hydrophones) capture the returning sound waves.

The cable containing hydrophones, called a streamer, is towed or 'streamed' behind a moving vessel. The hydrophones are mounted at regular intervals and towed behind the ship in a streamer. A total number of seismic hydrophones may even be a few hundred thousand, which allows to study once area from a few to several square kilometers.

The towing equipment is a complex, carefully designed arrangement of specialized equipment that enables the multiple streamers and source arrays to be positioned accurately behind the vessel. The number of towed streamers depends on a width of the SSV back deck, where are installed reels used for storage, deployment and retrieval of the towed seismic equipment. It is 4 for the SSV with a width of $16 \mathrm{~m}$, to 24 for the SSV with a width of $70 \mathrm{~m}$. The streamer length depends on the depth and type of the geological target for a given survey. Recent surveys in the North Sea have seen streamer lengths that were typically $3 \mathrm{~km}$, now 5 to $8 \mathrm{~km}$. In the Gulf of Mexico and offshore West Africa some surveys are using streamers up to $12 \mathrm{~km}$ in length. The streamers are towed behind the SSV with a controlled depth. Typically the range of operating depths varies from 4-10 m of shallow water, to $25 \mathrm{~m}$ in probably a majority of areas around the world, and to $100 \mathrm{~m}$ for deeper penetration in waters of a depth not exceeding 500 $\mathrm{m}$.

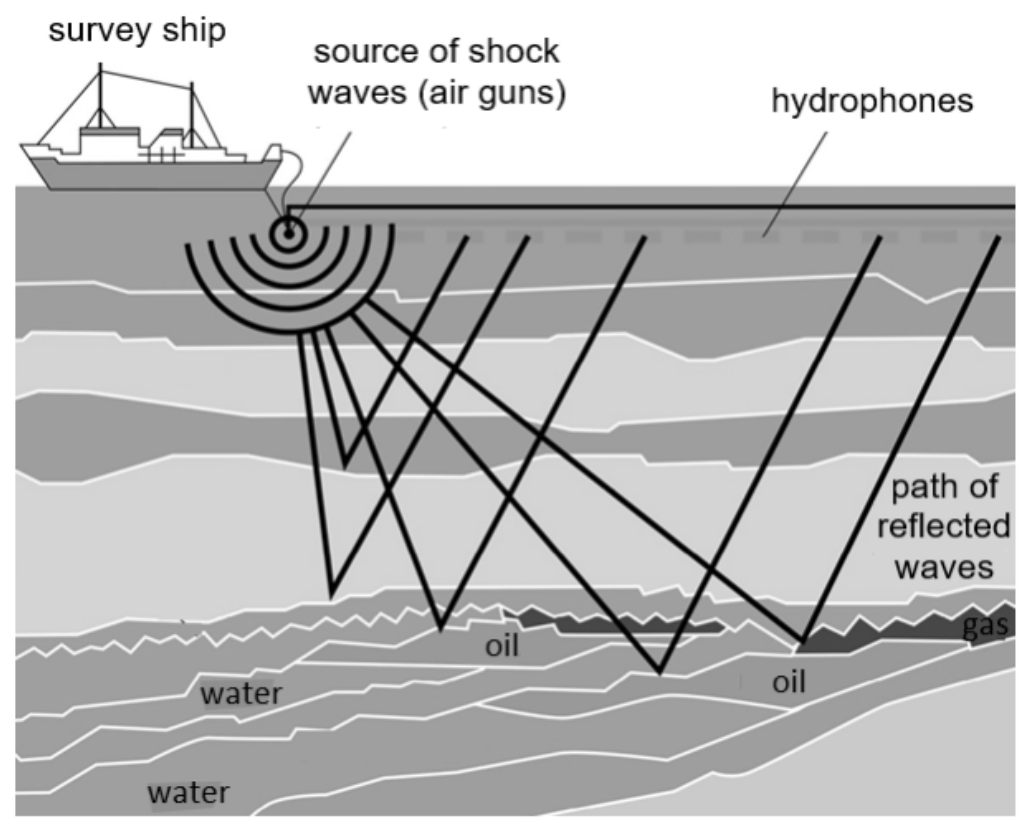

Fig. 2. Schematic explanation of seismic survey technique.

Source: Learning Geology, 2015

A more detailed description of offshore survey techniques applied in locating of offshore oil and gas reserves is presented in (Tarelko, 2016). 
A survey seismic vessel typically operates at a tow speed of between 4,5 and 5,0 knots. At this rate, the SSV could conceivably cover some 200 kilometers in a day and almost 6500 kilometers in one month. The main expenses of the offshore seismic survey are directly related to the costs of offshore operation. In 2008 they reached up to about 350 thousand USD per the working day of SSV. Today, with the introduction of more sophisticated seismic survey vessels equipped with the dedicated back deck for storage, deployment and retrieval of the towed seismic equipment, these costs decreased to 250 thousand USD per day.

However, these are still very high costs forced counteracting unforeseen disruptions in offshore operations due to any failures of the SSV power and propulsion systems. Therefore, the seismic survey vessels are now designed with structural redundancy of these systems located in separate machine compartments.

The most distinguishable offshore unit of SSV type is Ramform Thetys class Titan operated by Norwegian ship-owner PSG. Launched by shipyard Mitsubishi in Nagasaki in 2014, she represents an enormous stable platform, with the flexibility to encompass virtually any acquisition design.

This ship, like the other ships of the class Titan, has a fairly specific shape - looking from top is similar to the triangle. They are $104,2 \mathrm{~m}$ long and $70 \mathrm{~m}$ wide and they have 24 streamer reels: 16 abreast, and 8 in a second row. This solution enables to deploy 24 streamers of $12 \mathrm{~km}$ in length with gaps of $100 \mathrm{~m}$ between them. Apparently, it is the largest moving object in the world created by mankind, from the covered surface point of view.

Ramform Thetys was built under the supervision of DNV, and her ship power plant meets the $\mathrm{DNV}$ requirements of the class notation RP.

The plant in Ramform Tethys is based on six 3,84 MW Wärtsilä eight-cylinder engines in the main generators, making for a total power concentration of around $23 \mathrm{MW}$, and feeding three $6 \mathrm{MW}$ ABB electric propulsion motors driving three Wärtsilä controllable pitch propellers for a maximum propulsive effect of $18 \mathrm{MW}$. Sets of three generators and their prime mover diesels are located in two separate engine rooms isolated from each other by fir-resistance bulkheads. Ramform Tethys can carry out offshore survey seismic operations using:

- one set of her prime movers and generators located in one engine room,

- just two of her three drivelines.

This solution of her power plant permits maintenance of one set of her diesel electric propulsion system and one of three drivelines to be undertaken during offshore operations.

Both two engine rooms and three drivelines provide full redundancy of the ship power plant granted a high reliability of offshore seismic survey operations.

\section{Offshore Construction Vessel North Sea Giant}

Offshore construction vessels (OCV) are multi-purpose vessels used particularly by the oil and gas industry. The OCV North Sea Giant is one of the largest and most technologically advanced vessels designed to carry out highly specialized offshore subsea operations. Designed by the Norway designing corporation Sawicon and built at the Metal Ships and Docks shipyard based in Spain, the North Sea Giant put into active operational duty in 2011. She has a length of nearly $161 \mathrm{~m}$ and a breadth of $30 \mathrm{~m}$ with a draft of seven $\mathrm{m}$ and a depth of nearly $11 \mathrm{~m}$. This OCV is equipped with an unusual propulsion in a form of Voith Schneider Propellers (VSP) that combine propulsion and steering in one unit. This choice was dictated by the specifics of offshore operations carried out, which require fairly high accuracy station-keeping in any weather condition. It is particularly important in a case of installation of subsea equipment at high depth, which has to be placed in a specific location on the seafloor.

The most spectacular offshore operation of OCV North Sea Giant was the installation of new modules for Asgard gas compression subsea station. This station is located on the Norwegian Sea, about 200 miles from the shore on the average depth of 240 to $310 \mathrm{~m}$. Using 52 wells in 16 points, is one of the biggest investments on the Norwegian continental shelf. Because of falling natural pressure of gas from existing reservoirs (fields Mikkel and Midgard), additional gas compression has become a necessary condition to increase its output. 
To install 20 modules on a special frame of the mentioned station (Fig. 3) on the depth $300 \mathrm{~m}$, the Special Handling System (SHS) was installed on starboard of North Sea Giant. It is superstructure with an overall height approximately $31 \mathrm{~m}$ designed to be lowered and lift heavy subsea equipment (up to 420 tons) in poor weather conditions, with sea waves up to $4,5 \mathrm{~m}$.

The most weighty modules were launched by wires from the OCV starboard using the SHS system. These modules have a special guided pins, which should be placed in specially shaped holes prepared in the station frame. Tolerance range of this alignment did not excess than a few centimeters in the horizontal plane and ten centimeters vertically. This accuracy was ensured by the ship dynamic positioning and anti-heeling systems. All subsea operations were supervised by three Remotely Operated Vehicles (ROV), which also carried out mounting and dismounting operations. The installation time of the individual modules ranged from 3 to 5 days, whereas a cost of the complete project associated with the installation of the new modules for Asgard gas compression subsea station was assessed on 2,19 billion USD (Offshore magazine, 2015).

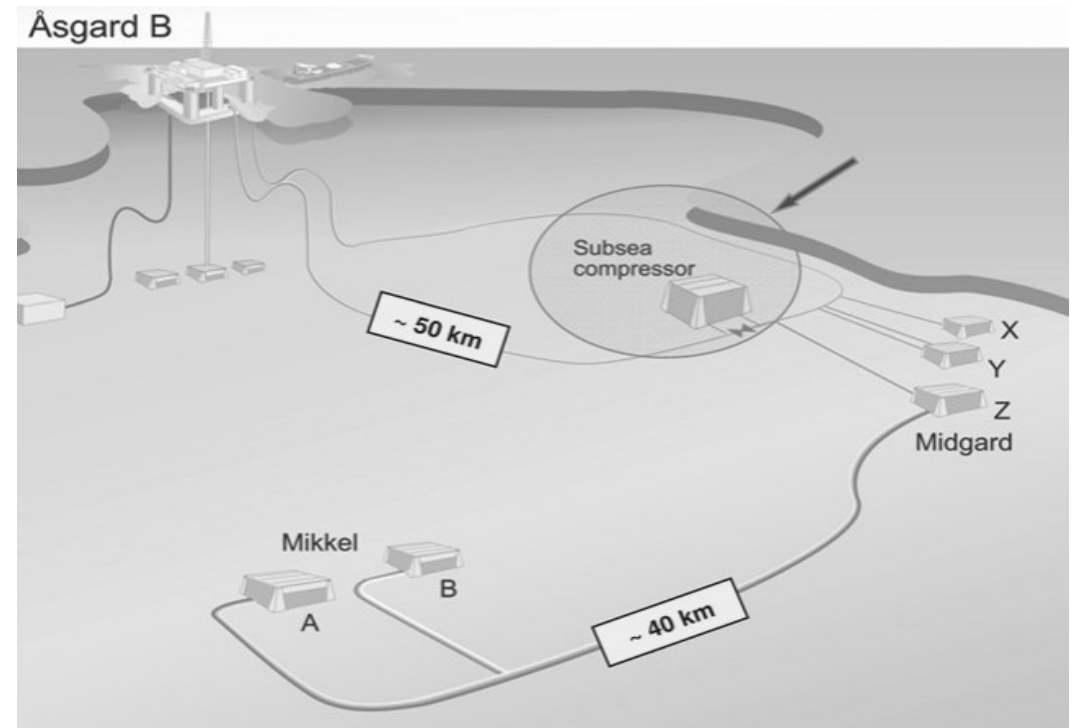

Source: StatoilHydro, 2010

Fig. 3. Field diagram of Asgard Subsea Compression.

The performance of such a costly project required to engage the OCV with a very high reliability of its ship power plant. Therefore, the North Sea Giant plant has been designed with the suitable structural redundancy.

A ship power plant of North Sea Giant is equipped with diesel electric propulsion systems with a total power of $19 \mathrm{MW}$. It has installed six Leroy generators driven by General Electric engines rated at 3.63 MW each (North Sea Shipping, 2013). The propulsion is provided by three VSP propellers with power $3.8 \mathrm{MW}$ each located on the vessel stern. In addition, North Sea Giant has installed two VSP and two Rolls-Royce tunnel thrusters located on the vessel bow. In high seas, the extremely fast and precise propeller control system allows the North Sea Giant to be kept safely and accurately on position. This is ensured by the dynamic positioning system (Kongsberg Autro DP3), which uses VSP thrust forces, as well as by the Voith Roll Stabilization (VRS). The VSP propellers ensure precise control, a high degree of propulsion efficiency and low fuel consumption, even in adverse weather and current conditions.

The power and propulsion system of North Sea Giant is unique because her power plant has three separate engine rooms containing in each two diesel generator systems and isolated compartments containing drive electric systems of VSP propellers (North Sea Shipping, 2011). This unique plant meets, in some ways, the requirements of the DNV class RPS that were published in the 2011 that is a year after launching of North Sea Giant. 
This solution ensures a full structural redundancy of the OCV power plant what ensure a very high level reliability of carrying out offshore operations connected with installation of subsea equipment at high depth even in case of fire or flooding one of the engine rooms.

\section{CONCLUSION}

Power and propulsion systems of any ships including offshore vessels must be of a very high level of reliability. To ensure carrying out safety of navigation and so expensive offshore operations in the most reliable way, various types of redundancies are built-in ship power plants. Despite application of a high level of redundancy in modern passenger ships and separation of their machine compartments, some malfunctions occurred in their ship power plants which threaten the safety of ships. The investigation reports released after accidents has been passed to the IMO for further consideration in order to take appropriate countermeasures increasing the navigation safety of passenger ships.

Application of a full structural redundancy in power plants of the offshore vessels ensure a very high level reliability of carrying out offshore operations in case of fire or flooding one of the engine rooms.

\section{REFERENCES}

American Bureau of Shipping (2015). Guidelines for Redundant Propulsion Systems and Navigation Integrated Bridge Systems. Available at: https://ww2.eagle.org/en/rules-andresources/rules-and-guides.html. [Accessed 12 Jun. 2018].

Center for Tankship Excellence. (2010). Amoco Cadiz (IMO 7336422): Summary for Casualty ID 19780316_001". Casualty Database.

Det Norske Veritas (2011). Rules for Classification of Ships. Part 6 Chapter 2. Newbuildings. Special Equipment and Systems. Redundant Propulsion.

International Maritime Organization. (2014). International Convention for the Safety of Life at Sea, 1974: Articles, Annexes and Certificates. Consolidated Edition 2014.

Johannessen I. A., McArthur P. W., and Jonassen J. R. (2015). Informal leadership redundancy: Balancing structure and flexibility in subsea operations. Scandinavian Journal of Management. No. 31 (3). 2015. pp. 409-423.

Learning Geology. (2015). Marine and land seismic acquisition. Available at: http://geologylearn.blogspot.com/2015/06/marine-and-land-seismic-aquisition.html. [Accessed 12 Jun. 2018].

Levine R.A, Witherspoon W., and Tragardh P. (2005). Disabled Ship Studies for the Polar Endeavour Class Tankers, SNAME.

Marine Accident Investigation Branch reports (2015). Engine failure and subsequent grounding of oil tanker Braer. Report of the Chief Inspector of Marine Accidents (9 Dec 1993). Available at: https://www.gov.uk/maib-reports/engine-failure-and-subsequent-groundingof-oil-tanker-braer-at-garths-ness-shetland-scotland. [Accessed 12 Jun. 2018].

North Sea Shipping (2011). Making advances. Available at: http://www.landseaairmagazine.com/2011/05/06/north-sea-shipping/ [Accessed 12 Jun. 2018].

North Sea Shipping (2013). Short spec. M/V North Sea Giant. North Sea Shipping AS. Available at: http://www.technip.com/sites/default/ files/technip/fields/spec_giant.pdf. [Accessed 12 Jun. 2018].

Offshore magazine (2015). Subsea compression prolongs gas production at Åsgard offshore Norway. Available at: http://www.offshore-mag.com/articles/print/volume-75/issue-12/top5-projects/subsea-compression-prolongs-gas-production-at-asgard-offshore-norway.html. [Accessed 12 Jun. 2018].

Polski Rejestr Statków. (2018). Rules for the Classification and Construction of Sea-going Ships. Available at: https://www.prs.pl/prs-rules-and-publications/classification-rules.html. [Accessed 12 Jun. 2018].

Spyrou A.G. (2006). From T-2 to Supertanker: Development of the Oil Tanker, 1940-2000, Lincoln, Nebraska: iUniverse.

StatoilHydro ASA (2010). Deep Water Construction Projects from both a Technical and Risk Management Perspective. Available at: http://www.cii.co.uk/knowledge/. [Accessed 12 Jun. 2018].

Tarelko W. (2012). Origins of ship safety requirements formulated by International Maritime Organization. Procedia Engineering No. 45. Elsevier Ltd. 2012. pp. 847-856. 
Tarelko W. (2016). Systemy poszukiwania złóż ropy naftowej i gazu pod dnem morskim. Przegląd Mechaniczny. Nr 12. pp. 50-54.

The Bahamas Maritime Authority (2013). Joint report of the investigation into an engine room fire on February 10th,. Carnival Triumph. Available at: https://ace-notebook.com/carnivaltriumph-fire-investigation-report-free-related-pdf.htm. [Accessed 12 Jun. 2018].

The Telegraph. (2013). Maersk brings world's largest ship into service. Available at: http://www.telegraph.co.uk/finance/newsbysector/transport/10162144/Maersk-bringsworlds-largest-ship-int. [Accessed 12 Jun. 2018].

Vogler U. et al. (2009). Safe Return to Port - Challenges Ahead for Passenger Ship Design, SNAME Symposia Papers.

Wärtsilä Encyclopedia of Marine Technology. (2015). V-Max tankers STENA VISION and STENA VICTORY. Available at: https://www.wartsila.com/encyclopedia/term/v-maxtankers-stena-vision-and-stena-victory. [Accessed 12 Jun. 2018].

Date of submission of the article to the Editor: 05/2018

Date of acceptance of the article by the Editor: 08/2018 